\title{
Petrology of Exposed Basement Rocks around Shintaku of North Central Nigeria
}

\author{
O. Od* \\ Department of Geology, Delta State University, Abraka, Nigeria
}

Received 8 June 2013, accepted in final revised form 28 August 2013

\begin{abstract}
The study area is part of the Basement Complex of North Central Nigeria. The study aims at identifying the rock types and interpretation of the structural elements. The major rock units in the area comprises of porphyritic granite, gneiss and schist. Structural evidence shows that the rocks are deformed and where intruded by the granite. Petrographic analysis reveals the existence of feldspar phenocrysts in a groundmass of quartz and biotite. The granite is composed of quartz (25-35\%), plagioclase (15-20\%), orthoclase (10-20\%), microcline $(5-25 \%)$, biotite $(15-20 \%)$ and other accessory minerals. The granites displayed a porphyritic texture while the schist and gneisses exhibit planar and linear structures. Variation in structural trend and mineralogical composition is due to the series of deformational activities which has affected the rocks during geologic time.
\end{abstract}

Keywords: Monzogranite; Porphyritic; Deformation; Fractionation.

๑) 2013 JSR Publications. ISSN: 2070-0237 (Print); 2070-0245 (Online). All rights reserved. doi: http://dx.doi.org/10.3329/jsr.v5i3.15233 J. Sci. Res. 5 (3), 489-497 (2013)

\section{Introduction}

The Basement Complex of Nigeria lies within the Pan-African mobile belt [1] of Proterozoic age. The Shintaku area is part of the basement complex of Nigeria and is underlain mainly by granites, gneisses and schists. It falls within the North Central Nigeria and is located within latitudes $7^{0} 41^{1}-7^{0} 49^{1} \mathrm{~N}$ and longitude $6^{0} 45^{1}-6^{0} 50^{1} \mathrm{E}$ (Fig. 1). Several workers on the Nigerian Pan-African Belt have studied the origin, structural elements, geochemistry, petrology and among others. [2] reported that the last stage of the Pan-African orogeny is represented by conjugate fracture system of strike-slip faults. [3] estimated the feldspar resort around Odobola at about 119 million tons. This research work examines the geology, petrography and geological structures associated with the exposed rocks.

\footnotetext{
*Email: odededeo@yahoo.com
} 


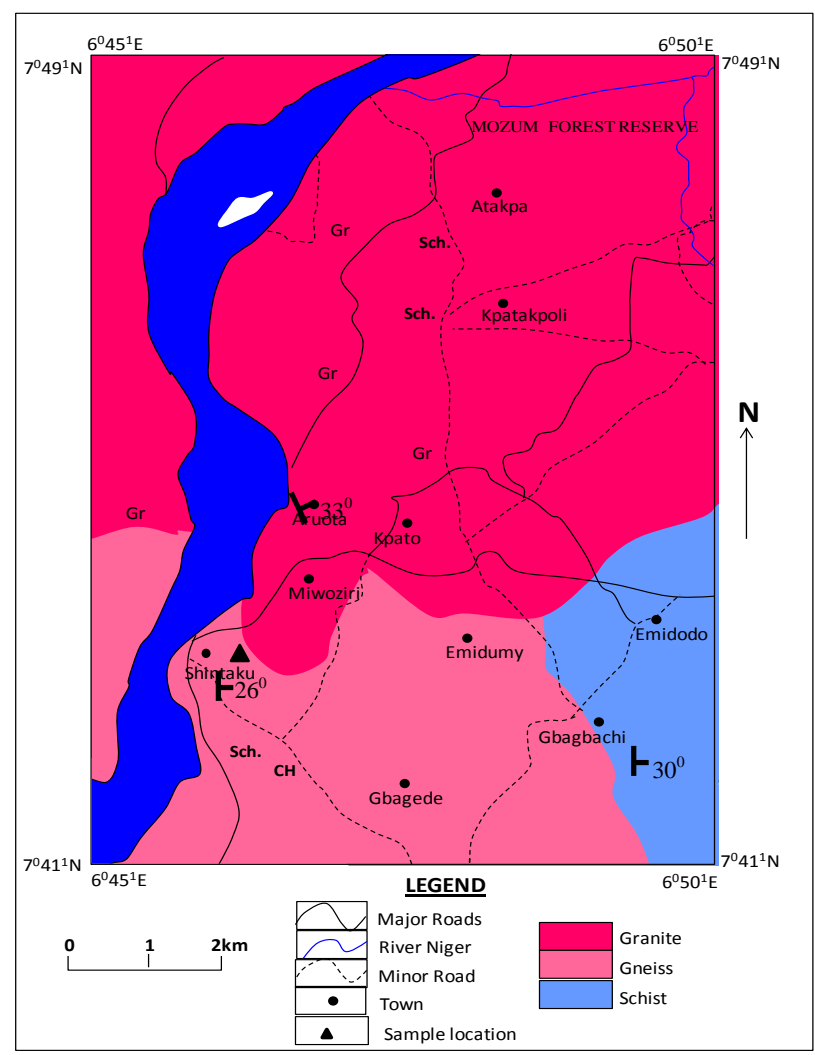

Fig. 1. Geological map of study area.

\section{Geologic Setting}

Precambrian rocks of Nigeria occur east of the West African Craton, northwest of the Congo Craton, and south of the Tuareg shield. The region was affected by the Pan African orogeny about $600 \mathrm{Ma}$. Geochemical evidence indicates that the Nigerian basement is polycylic and includes rocks of Archean $(2.0$ - 3.0 Ga) era together with those of Eburnean (2000 $\pm 200 \mathrm{Ma}$ ) and Pan African (750 $\pm 450 \mathrm{Ma}$ ) events [4]. Granitoid plutons of the older granites suite are considered as syntectonic to late tectonic granitoids emplaced during the pan Pan African [5]. The basement complex rocks are subdivided into migmatite-gneiss complexes, the older metasediments, the younger metasediments, the older granites and younger granite alkaline ring complexes and volcanic [6]. Older granites are widespread throughout the basement complex, the granitoids have been emplaced into both the migmatite-gneiss complex and the schist belts and they occur in all parts of Nigeria [6]. Recent works in different parts of the Nigeria Basement Complex has shown that older granites are high level intrusions emplaced by stopping [7]. 


\section{Methodology}

A systematic mapping of the area was carried out on the exposed outcrops (granite, gneiss and schist) using the base map extracted from the topographic map sheet of Lokoja on a scale of 1:690 and a global positioning system to record coordinates of the location on the base map, strike and dip values were measured for the host rock with the aid of compass clinometer. Sampling was done randomly and was assigned numbers (Table 1). Thereafter, outcrops were observed, described, identified in order to determine their textural and structural characteristics, as well as their mode of occurrence. Thin sections of the ten (10) rock samples were prepared and analyzed for petrographic studies. Photographs and photomicrographs of interest were taken where necessary.

\section{Petrography}

During the field mapping exercise, different rocks were observed and their physical and textural characteristics examined. The study area basically consists of three (3) main lithologies; granites, gneisses and schist (Fig. 1).

\subsection{Granite}

Granite occurs around Shintaku, fine to medium grained and massive. It is characterized by quartz veins, and joints. It displays a variety of colored minerals in hand specimen which range from grey to brown and pink especially the porphyritic granite which display akali feldspar phenocrysts while biotite constitute the groundmass.

In thin section, it contains quartz, plagioclase, biotite, microcline and other accessory minerals (Fig. 2). The quartz is colorless with euhedral shape. Other minerals like microcline show cross hatched twining and classification scheme of [8] falls within the monzogranites (Fig. 4).

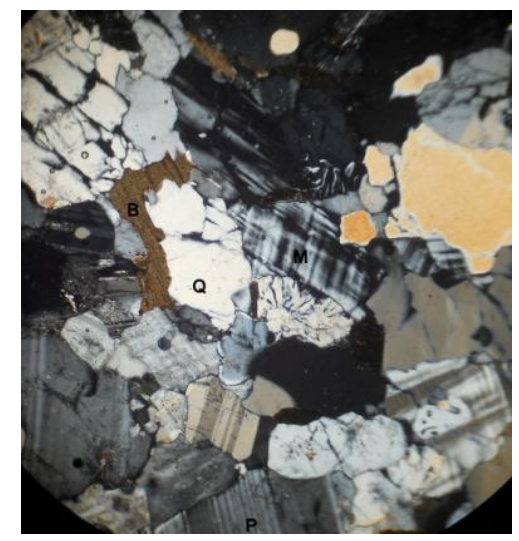

Fig. 2. Photomicrograph of Alkaline feldspar in granite around Shintaku. 


\subsection{Gneiss}

Gneiss (Fig. 3) is found at around the studied area. It is fine to medium grained, foliated, with bands of light and dark colored minerals. There are quartz veins running concordantly to the rock surface and some cross cutting. Fracturing and folding such as chevron folds that are asymmetrical are present. Petrographically, it exhibit variable mineral grains closely packed with preferred orientation. The dominant mineral (Table 1) observed include biotite, feldspar and quartz. The K-feldspar occurs as pink anhedral grains, moderate cleavage and twinned. The biotite display greenish to brown weak pleochroism.

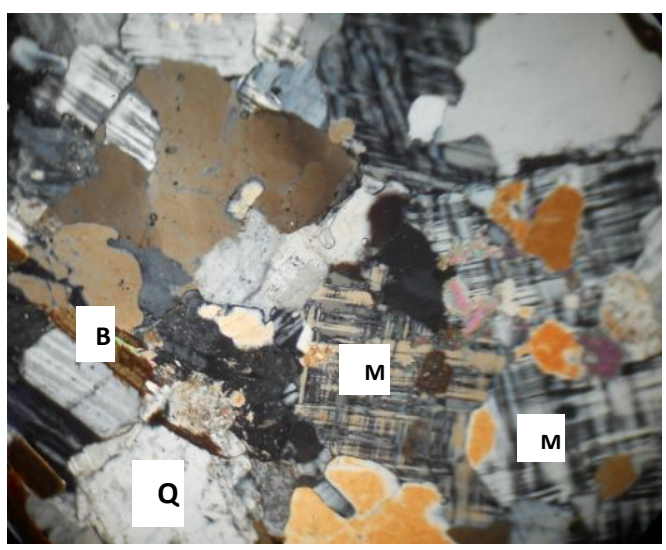

Fig. 3. Photomicrograph of biotite (B), quartz (Q), microcline (M) in granite around Shintaku.

Table 1. Mineral composition of granitic rock around Shintaku.

\begin{tabular}{|c|c|c|c|c|c|c|c|c|c|c|}
\hline \multirow[t]{3}{*}{ Minerals } & \multicolumn{10}{|c|}{$\%$ Mineral composition of the rocks } \\
\hline & Sample & Sample & Sample & Sample & Sample & Sample & Sample & Sample & Sample & Sample \\
\hline & 1 & & & & & & & & & \\
\hline Quartz & 25 & 30 & 35 & 30 & 40 & 35 & 30 & 45 & 20 & 35 \\
\hline $\begin{array}{l}\text { Alkali- } \\
\text { feldspar }\end{array}$ & 10 & 10 & 15 & 20 & 15 & 20 & 10 & 10 & 20 & 15 \\
\hline Plagioclase & 15 & 20 & 20 & 20 & 10 & 15 & 20 & 20 & 15 & 15 \\
\hline Microcline & 25 & 20 & 10 & 5 & - & 10 & 20 & 15 & 10 & 10 \\
\hline Biotite & 15 & 15 & 10 & 10 & 10 & 5 & 15 & 5 & 10 & 15 \\
\hline Hornblende & - & - & 5 & 10 & 5 & 5 & - & - & 15 & 10 \\
\hline $\begin{array}{l}\text { Accessory } \\
\text { minerals }\end{array}$ & 10 & 5 & 5 & 5 & 20 & 10 & 5 & 5 & 10 & 10 \\
\hline
\end{tabular}




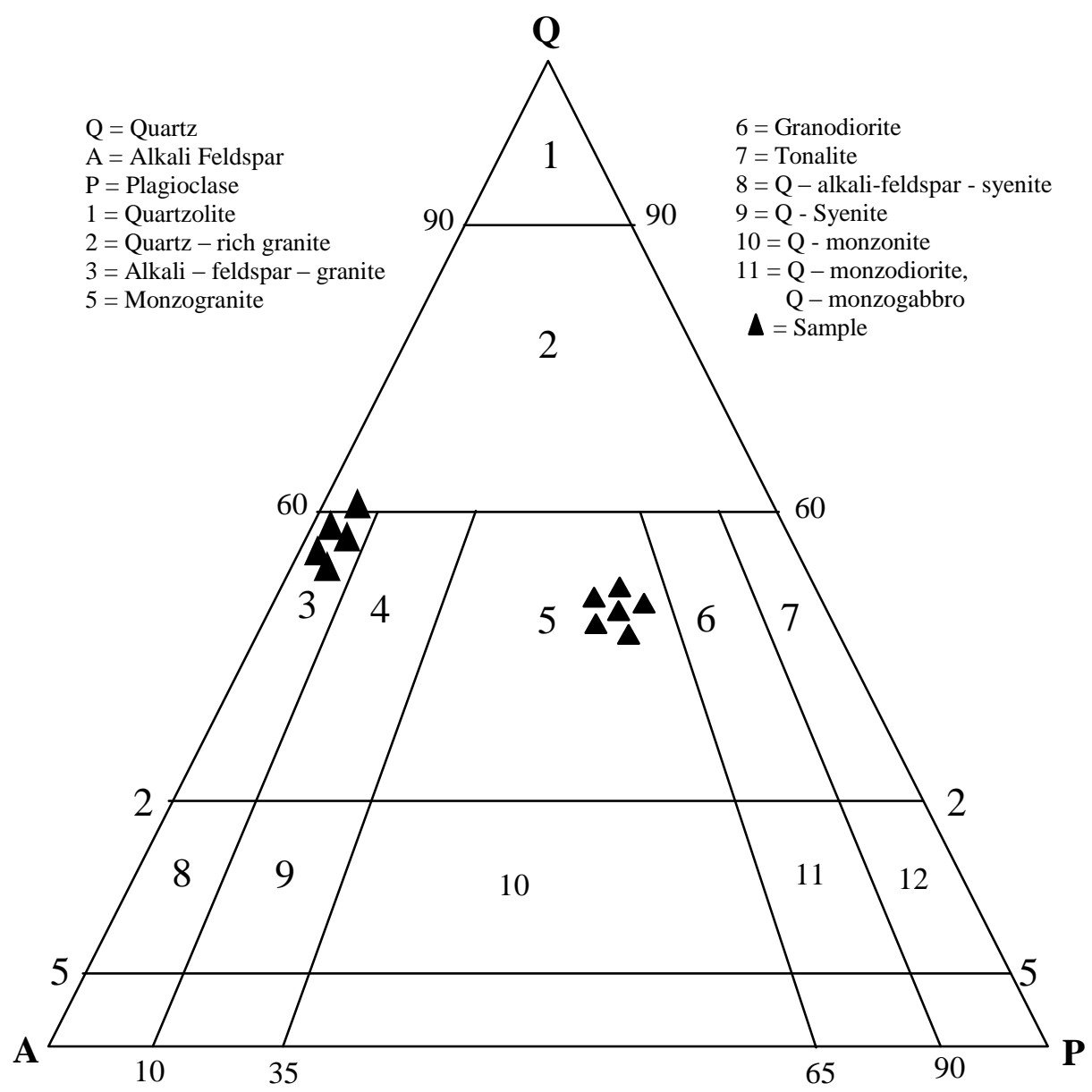

Fig. 4. QAP diagram for Shintaku granite/ gneiss [8].

\subsection{Schist}

The study area is also made up of schists. The schists are the oldest rocks in the area and have been intruded by Pan-African granite in some places. They are foliated and folded, the foliation are represented by the ferromagnesian minerals and quartzo-feldspathic minerals.

\section{Structural Geology}

The noticeable structures encountered in the mapped area include; fractures, veins, lineation, foliation, and folds. Shear fractures observed on the granites are either filled by 
late pegmatitic veins or display evidence of free aperture (Fig. 5). Fractures which ranges from $3 \mathrm{~mm}$ to $28 \mathrm{~cm}$. fillings are monogenic and monophase. High fracture density are observed in the granite compared to the low density on the schist, this may indicate surface stress relaxation effects during the un-roofing of the granite in Precambrian times. Variable dip angles and direction characterize the strike joints of the granites and gneisses. Genesis of these structures (Fig. 5) may be attributed to visible expressions of residual stresses released after deformation.

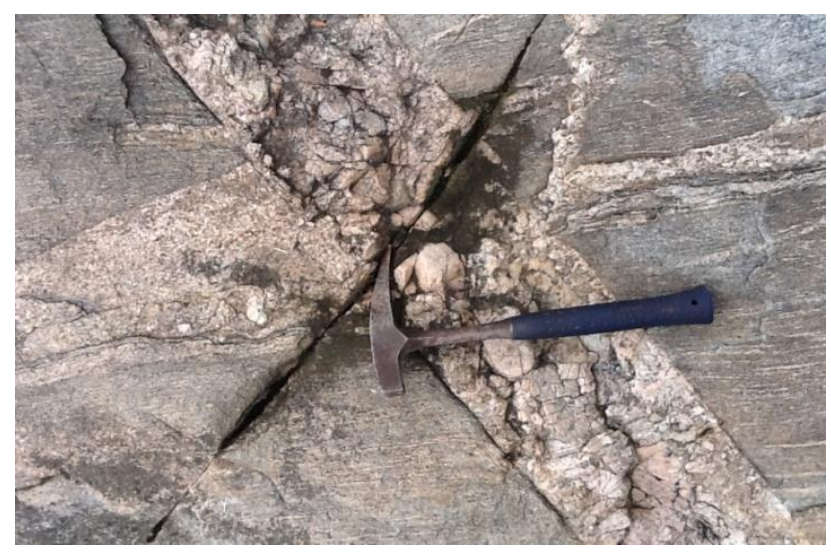

Fig. 5. Shear fractures and pegmatitic veins in gneissic rock around Shintaku.

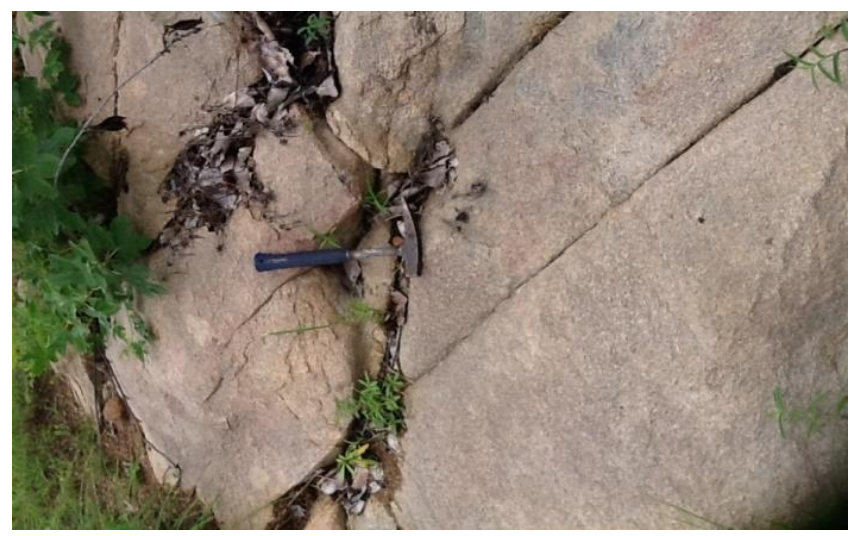

Fig. 6. Shear Fractures in granite rock around Shintaku.

Both quartz and pegmatitic veins are found in the rocks of the studied area. The veins are irregular. Some of them run parallel to the general structural NW-SE trend, while 
others crosscut (Fig. 7) especially the quartz veins. It can be inferred that they formed at a later age.

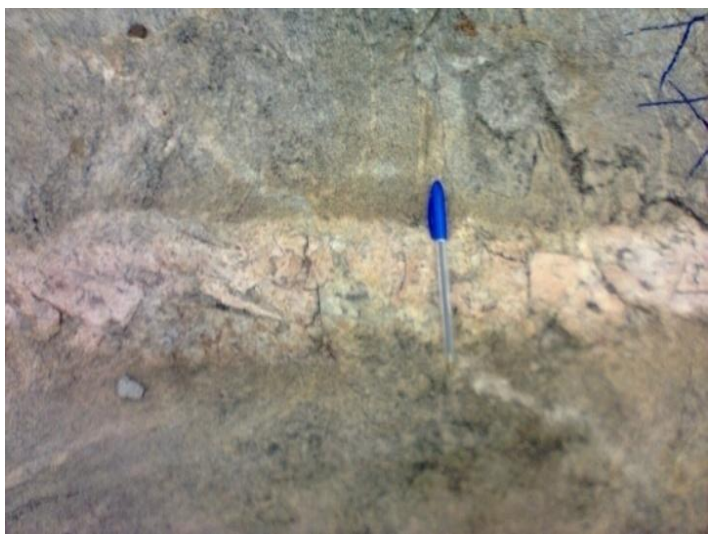

Fig. 7. Crosscutting quartz veins around Shintaku, North Central Nigeria.

\subsection{Folds}

Antiformal and synformal folds were encountered on the gneiss. The crest measures $1.3 \mathrm{~m}$ and culminations vary considerably with various crest lines (Fig. 8). This may be due to compressional forces to which these rocks have been subjected overtime. From close observation chevron fold with series of anticlines and synclines were noted (Fig.8). The limbs of the folds are asymmetrical, and exhibit open fold. Foliations were also observed.

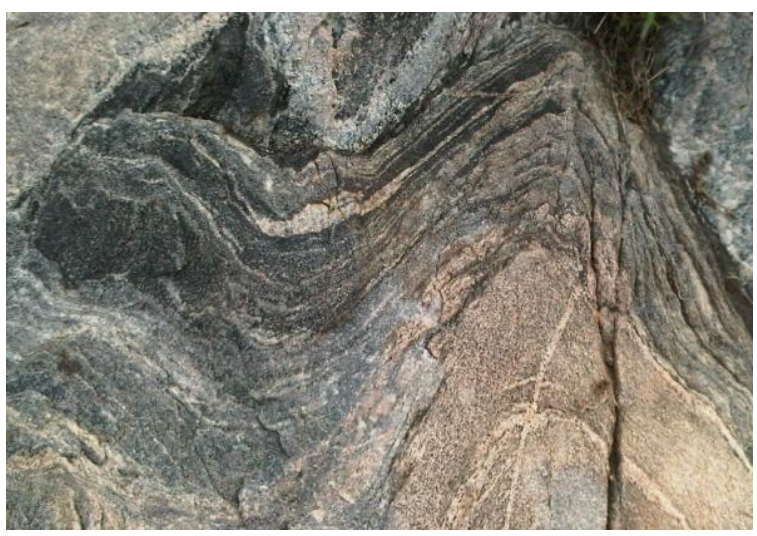

Fig. 8. Antiformal and synformal folds in gneissic rock around Shintaku. 
Lineation and foliation also occur in most of the gneisses encountered. They probably developed as a result of tectonic differentiation. The preferred orientation (Fig. 10) of the foliation is NW-SE trending which is indicating imprint of the Pan-African orogeny.

\section{Discussion}

Field and petrography show that granite, gneiss and schist in the study area have been deformed due to the presence of antiformal and synformal folds and shear fractures. [5], reported that most of the granites and gneisses in the Nigeria Basement Complex are intrusive while $[9,10]$ used partial melting of crustal rocks to evoke the genesis of the granite-gneiss of North-Central Nigeria. Pegmatites and quartz veins also intruded the granites. These are coarse grained and quartzo-feldspathic. Granites species that dominated the study area include alkali-feldspar granite and monzogranite. The granite varies between medium to coarse grained while the gneisses are fine grained and exhibit lineation and foliations structures suggesting polyphase deformational history. Chevron folds occurs minor structures on the gneiss and may have been formed in response to lateral compression of the rocks possibly due to heat accompanied by magmatic activities that emplaced the granitic pluton [10-11], attributed differentiation of the magma at higher structural levels in addition to partial melting of crustal rocks to generate an acid magma. The present study lends support to this interpretation.

\section{Conclusion}

Field relationship between the rocks of the studied area shows that the granites and gneisses are magmatic in origin. They are characterized by fractures, folds and planar and linear structures. These structures are signatures of polyphase deformation and residual stresses released after deformation of the granitic gneiss.

\section{References}

1. R. Caby, Pre-Cambrian Terrains of Benin-Nigeria and Northeast Brazil and Late Proterozoic South Atlantic rift, Geological Society of America of Northern Nigeria (Macmillian, London, 1989) p. 295.

2. I. Garba, Nigeria. J. Min. Geol. 38 (1), 1 (2002).

3. A. I. Agbor and O. U. Shehu, Earth Sci. Res. 2 (1), 52 (2013). http://dx.doi.org/10.5539/esr.v2n1p52

4. A. A. Ibrahim, Nigeria. J. Min. Geol. 44 (2), 13 (2008).

5. P. McCurry, Geology of the Precambrian to Lower Paleozoic rocks of NW Nigeria, A review: In: C. A. Kogbe (ed.) Geology of Nigeria ( $2^{\text {nd }}$ ed.) (Elizarbethan Pub., Lagos, Nigeria, 1989) pp. 15-39.

6. A. C. Ajibade, Nigeria. J. Min. Geol. 19, 223 (1982).

7. W. R. Fitches, A. C. Ajibade, I. G. Egbuniwe, R. Holt, and J. B. Wright, J. Geol. Soc. London, 142, 319 (1985). http://dx.doi.org/10.1144/gsigs.142.2.0319

8. A.W .Streckeisen, Earth Sci. Rev. 12 (1), 1 (1976). http://dx.doi.org/10.1016/0012-8252(76)90052-0 
9. M. A. Rahaman, and O. Ocan, Nigeria. J. Min. Geol. 15 (1), 23 (1978).

10. O. I. Imasuen, J. A. Olatunji, and V. T. Ibitoye, J. Sci. Multidisci. Res. 2,87 (2010).

11. A. A. Elueze, O. O. Kehinde-Phillips, and O. A. Okunlola, Nigeria. J. Min. Geol. 44 (1), 21 (2008). 